\title{
Practical Theology and providing service: The service through love of the Mamas Africa in the South African society
}

\begin{tabular}{|c|c|}
\hline \multicolumn{2}{|c|}{$\begin{array}{l}\text { Author: } \\
\text { Amanda L. du Plessis }{ }^{1}\end{array}$} \\
\hline $\begin{array}{l}\text { Affilation: } \\
{ }^{1} \text { Unit of Refor } \\
\text { and the Devel } \\
\text { the South Afri } \\
\text { North-West U } \\
\text { Potchefstroon } \\
\text { South Africa }\end{array}$ & $\begin{array}{l}\text { ned Theology } \\
\text { pment of } \\
\text { fan Society, } \\
\text { hiversity, } \\
\text { Campus, }\end{array}$ \\
\hline $\begin{array}{l}\text { Note: } \\
\text { This article wa } \\
\text { a paper delive } \\
\text { conference on } \\
\text { Theology and } \\
\text { delivery' of th } \\
\text { Practical Theo } \\
\text { the North-We } \\
\text { Potchefstroon } \\
25 \text { January } 20 \\
\text { is published in } \\
\text { Practical Theo } \\
\text { Society for Pra } \\
\text { in South Africa }\end{array}$ & $\begin{array}{l}\text { s initially } \\
\text { red at the } \\
\text { 'Practical } \\
\text { Service } \\
\text { Society of } \\
\text { ogy, held at } \\
\text { t University, } \\
\text { Campus, 23- } \\
\text { 13. This article } \\
\text { the section } \\
\text { ogy of the } \\
\text { ctical Theology } \\
\text {. }\end{array}$ \\
\hline $\begin{array}{l}\text { Corresponder } \\
\text { Amanda du PI }\end{array}$ & $\begin{array}{l}\text { ce to: } \\
\text { essis }\end{array}$ \\
\hline $\begin{array}{l}\text { Email: } \\
\text { amanda.duple }\end{array}$ & sis@nwu.ac.za \\
\hline $\begin{array}{l}\text { Postal addres } \\
\text { Private Bag X6 } \\
\text { Potchefstroon } \\
\text { South Africa }\end{array}$ & 2520, \\
\hline $\begin{array}{l}\text { Dates: } \\
\text { Received: } 29 \mathrm{~J} \\
\text { Accepted: } 30 \\
\text { Published: } 12\end{array}$ & $\begin{array}{l}\text { an. } 2013 \\
\text { May } 2013 \\
\text { eeb. } 2014\end{array}$ \\
\hline $\begin{array}{l}\text { How to cite th } \\
\text { Du Plessis, A.L } \\
\text { 'Practical The } \\
\text { providing serv } \\
\text { through love } \\
\text { Africa in the S } \\
\text { society', HTS } \\
\text { Studies/Theol } \\
70(2), \text { Art. \#19 } \\
\text { http://dx.doi. } \\
\text { hts.v70i2.193 }\end{array}$ & $\begin{array}{l}\text { is article: } \\
\text { 2014, } \\
\text { logy and } \\
\text { ce: The service } \\
\text { f the Mamas } \\
\text { puth African } \\
\text { eologiese } \\
\text { gical Studies } \\
31,7 \text { pages. } \\
\text { rg/10.4102/ }\end{array}$ \\
\hline $\begin{array}{l}\text { Copyright: } \\
\text { (C) 2014. The } A \\
\text { Licensee: AOS } \\
\text { OpenJournals } \\
\text { is licensed unc } \\
\text { Creative Comr } \\
\text { Attribution Lic }\end{array}$ & $\begin{array}{l}\text { uthors. } \\
\text { S } \\
\text { This work } \\
\text { er the } \\
\text { lons } \\
\text { ense. }\end{array}$ \\
\hline 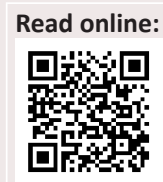 & $\begin{array}{l}\text { Scan this QR } \\
\text { code with your } \\
\text { smart phone or } \\
\text { mobile device } \\
\text { to read online. }\end{array}$ \\
\hline
\end{tabular}

A fundamental principle of the Christian faith is that man is saved by the grace and by faith in the Triune God, not by deeds. Yet, James emphasises the importance of works after the Christian has been saved. Jesus said during his ministry on earth that he did not come to be served, but to serve. Faith is therefore seen in deeds, specifically deeds of love, that is, deeds that indicate that the Christian is not leading an egocentric life anymore, but a life characterised by considering his or her fellow human beings and reaching out to them. Eighteen years after apartheid, South Africa is still a country striving to build a nation and to be healed. Marches and protests against poor public service deliveries have become a well-known sight in society. Despite the larger picture of inadequate service, there are those who serve their fellow humans and society every day. The Mamas Africa utilising the minimum resources available, are examples of people who make a difference in society every day. The concept Mama Africa indicates all women from all races who are making a difference in the South African society by promoting mutual bonding. The motivation for their deeds is a deep faith in God, who is the source of hope and a conviction that a Christian has to serve others.

\section{Introduction}

Paul writes to the congregation of the Galatians, ' $[b]$ ut what matters is a faith that expresses itself through love' (Rm 5:6). He continues:

You were indeed called to be free, brothers and sisters. Don't turn this freedom into an excuse for your corrupt nature to express itself. Rather, serve each other through love. (Rm 5:13)

A fundamental principle of the Christian faith is that man is saved through the grace of and by faith in the Triune God, not by deeds. Yet, James emphasises the importance of works after the Christian has been saved. Jesus said during his ministry on earth that he did not come to be served, but to serve. Faith is therefore seen in deeds, specifically deeds through love, that is, deeds that indicate that the Christian is not leading an egocentric life anymore, but a life characterised by consideration for his or her fellow human beings and reaching out to them.

Eighteen years after apartheid, South Africa is still a country striving to build a nation and to be healed. Marches and protests against poor public services have become a well-known sight in society. As South Africa is still a developing country that is trying to overcome the wounds caused by apartheid, such actions are not conducive to mutual bonding between the different race groups and cultures or to building a nation. Politicians plead that the South African people should make a renewed effort to live up to the concept of ubuntu. Boraine (2008) explains the appeal as follows:

South Africa needs to rediscover the core meaning of Ubuntu if it wishes to continue the process of reconciliation. With crime statistics soaring and a high incidence of violent crime ... it seems as if Ubuntu is a romantic notion that is practiced in the breach. To recognize and to affirm our common humanity in South Africa is essential if our social fabric is not to be torn asunder. (p. 215)

Ubuntu refers to the essence of the African concept of what it means to be a human being. It is a general term for all the different views embodied in African anthropology. The African theologian Mbiti summarises the concept, saying ubuntu essentially means 'a human being is always in relationship with other human beings' (LenkaBula 2008:378-379). Mnyaka and Maotlhabi (2005:217) emphasise that the concept of $u b u n t u$ has a wider meaning than only indicating positive human qualities when they say, 'it is about being and this disposition contributes to the well-being of others and the community.'

Archbishop Emeritus Desmond Tutu (quoted by LenkaBula 2008:381) describes ubuntu as the humane way in which people treat others, which then inspires them to become involved with 
their fellow human beings and service to others. When society becomes involved with fellow human beings in this edifying way, mutual bonding and building a nation are promoted and the wounds of apartheid may be healed by mutual trust and support. The ubuntu philosophy, as described here, is to my mind an application or realisation of the command of Paul in Galatians. Christians are called upon to realise love practically in society; eventually, it is this lifestyle of serving each other and reaching out to each other that brings about healing of a society.

Despite the larger picture of inadequate services in South Africa, there are those who serve their fellow humans and society every day. Although there are many examples of such people, I chose, for purposes of this article, to conduct a qualitative research on women who serve others at grassroots level because of their faith and inner conviction. These Mamas Africa are examples of people who make a difference in society every day by utilising the minimum resources available. The concept Mama Africa indicates all women from all races who are making a difference in the South African society by promoting mutual bonding. The motivation for their deeds is a deep faith in God, who is the source of hope (Rm 15:13), and the conviction that a Christian has to serve others. The central theoretical argument of this research is that if the example of these Mamas Africa would be followed with regard to their service through love, it could make a positive contribution to mutual bonding amongst the people of South Africa. The research question that had to be answered is the following: What is the relevance of the Christian command 'Serve through love' to the service of the Mamas Africa in the South African society? The research method used was a combination of a study of subject-relevant literature and empirical research and it is based on Osmer's (2008) research model for practical theology. The research is conducted according to the four tasks of which the model consists, namely:

- Descriptive task of priestly listening in a spirituality of presence (Osmer 2008:33). In this section, a qualitative investigation was undertaken into the activities of the women who serve their society through love every day.

- Interpretative task in a spirituality of sagely wisdom (Osmer 2008:81). In this section, the findings of the empirical research were evaluated.

- Normative task in a spirituality of prophetic discernment (Osmer 2008:135). In this section, the normative aspects concerned with the Christian's service compelled by love were investigated from a Reformational viewpoint.

- Pragmatic task in a spirituality of servant leadership (Osmer 2008:183). Finally, the focus fell on the way in which the findings of the research could be applied to praxis in order to make a difference in the South African society by showing Christian love in serving others.

With a view to the logical presentation of the argument, the normative aspects are presented first, then the descriptive and interpretative aspects of the empirical findings and finally the pragmatic aspects.

\section{Practical Theology and service: The command believers receive to serve through love}

In this section the normative aspects concerned with the Christian's service compelled by love are investigated from a Reformational viewpoint, that is, according to Osmer's normative task in a spirituality of prophetic discernment (Osmer 2008:135).

Olthuis (2012) published an article in which he pleads for a Christian post-postmodern world view. Where modernism emphasised logic, reason and science at the one end of the continuum, and postmodernism moved over to the other end of the continuum to search for an answer to the issues of life in the abstract, emotional and experiential. To modernism, differences or being different is oppositional. Olthuis (2012:2) refers to Freud, Hegel and Sartre, who were according to him, the most influential modernist philosophers because of their view that there are only two options in life, namely to dominate or to be dominated. To Freud love for the neighbour is only possible at the expense of love for the self. Postmodernism, on the other hand, did not see otherness as a threat, but it assumed an attitude of inclusiveness regarding mutual differences. Olthuis (2012:2) refers to it as an 'economy of love', because being a genuine community means 'being together in difference and diversity, rather than marginalisation or fusion into sameness - in, through and despite adversity.' He says however, that though this inclusive attitude may seem to be a good idea, it is an unrealistic, an unreachable target in the broken world with its present 'economy of violence'. In this milieu, Olthuis (2012:2) proposes a post-postmodern biblical world view that requests respect for differences. He finds the biblical mandate in Leviticus 19:

When an alien lives with you in your land, do not ill-treat him. The alien living with you must be treated as one of your nativeborn. Love him as yourself, for you were aliens in Egypt. I am the LORD your God. (vv. 33-34)

Christians are therefore responsible to live up to the 'economy of love' as the only counterpart for the 'economy of violence'. This does not mean tolerance of others because everything is acceptable, good and right, but living according to biblical values and norms in society. One of these biblical values is living up to the command to serve each other through love. According to Olthuis (2012:2), living according to biblical values is then no longer an obstacle to communication because of differences, but a starting point for evangelisation. In the broken world, this is the moment when Christians are the 'salt of the earth' and 'image bearers of God', because they have found their identity in God and live according to his demands in this world. In the priestly prayer of John 17 Jesus prays that believers may receive eternal life which was made possible by his death of atonement on the cross. Because of Jesus' sacrifice, the believer may know and love God (Jn 17:3; Kossé 2006:1288). However, knowing God is not merely a cognitive conviction of the believer, but his or her entire life 
is affected and influenced by this knowledge. The believer may therefore not live in self-indulgence anymore, but he or she must live up to their religious convictions in the practice of the world. Lawler (2004) states that knowing and loving God means acting like God:

To know God is not, as it is in Greece, to know that God is and what God is; it is, in Hebrew religion, to love God and act like God ... to know God as liberator is to liberate, is to do justice, always remembering how Yahweh intervened in history. (p. 10)

According to Van der Walt (1999:18), a normative Christian faith means Christians will follow Christ practically by obeying the will of God in all situations. This is illustrated in John 13:1-11, which describes the revelatory-historical event of Jesus' washing his disciples's feet. Jesus' action is reflected in his command to his disciples that they should act likewise by washing one another's feet (Jn 13:14-17). This will take them on the same road as their Master. The practice and mission of Jesus are continued by the practice and mission of his own in the midst of a hostile and violent world (Zorrilla 1995:74). Because of their belief in God, believers are free to serve others through love (Gl 5:6, 13; Adeyemo 2006:1423). In the new Testament, there are at least 300 references to 'serve', 'to serve' or 'servant' (Getz 1989:10). The most frequent words are douleő and diakoneő (Getz 1989:10). Douleó literally means to be someone's slave, to serve, to be obedient - in total commitment. Diakoneő means to serve others. It is the word from which the concept of deacon is derived and that refers to the office of a deacon in the church (Breed \& Breed 2010:627). In Galatians 5:13, the word douleo" is used to encourage believers to serve each other through love. 'In its strongest sense, this word described a person who gave himself up completely to another's will' (Getz 1989:11). This concept is used at least 160 times in the New Testament and indicates reaching out to or serving others in the most committed manner because of one's religious convictions.

The motivational force to serve others is Christian love, which is at the basis of all the gifts of the Spirit (1 Cor 13; Vorster 2011:7). According to Lawler (2004:19), covenant love is the reason for reaching out to society, as 'covenant love is willing and giving love, not just feeling and getting love.' In the Old Testament, the concept of hesed (Ex 20:6; 34:6) and in the New Testament the concept of agape (1 Jn 4:7-12) are used to describe the covenant love of God for the human being. Lawler (2004:19) refers to agape love as 'willing and active love, self-giving love, forgiving love, persevering and steadfast love. That is the love the Bible commands for Christians.' The author continues, ' love evinces a preference for the least in society, the poor, the oppressed, the voiceless underside'.

All things considered, the Christian then has the responsibility to show the love of Jesus in their attitude towards society. Just as God is compassionate love and God with us (Emmanuel), believers ought to embody love and resist evil (Olthuis 2012:1). The believer must serve others with the empathy, care and love of Jesus. Although it may be easier to be apathetic in many cases, believers must not remain silent about the many challenges that society experiences because of the self-indulgent life of its members.

According to Moltmann (1978:19), to be confronted by evil and suffering is not a bad experience as such; however, such a situation becomes dangerous when believers become accustomed to it, accept it as the norm and show an apathetic attiude towards it. When the covenant relationship of believers with God becomes the antidote to their apathetic behaviour, Moltmann (1978) is convinced of the following effect:

Their whole life would be shaped by sympathy, by compassion. We would suffer with God's suffering in the world, and rejoice with God's rejoicing over the world. We would do both at the same time and with the highest intensity because we would love, and with the love of God we would go outside ourselves. (p. 23)

The trust, faith and hope in God of believers compel them to become involved in society. If that happens, believers do not display a self-indulgent attitude of 'we' and 'they' anymore, but they themselves identify with the pain and lostness of the world and choose to live up to their faith in practice. Moltmann (1978) wants to know where the true church of God is supposed to make a difference and provides the answer himself:

Where is the true church? The true church is where Christ is. Christ is present in the mission of the believers and the suffering of 'the least of these.' His community is therefore the brotherhood of the believers and the poor, the lovers and the imprisoned, the hopers and the sick. The apostolate says what the church is; 'the least of these' says where the church belongs. Only if the church realizes in itself this double brotherhood of Christ does it really live in the presence of the crucified and exalted Christ. (p. 105)

According to Ramphele (2012:177), the world is beginning to understand the importance of not only acknowledging social pain, but also addressing it in a culturally appropriate way within each context. What is no longer in dispute is that social pain is a major determinant of ill health and an obstacle to sustainable development. When the South African people strive to build a nation, the wounds of apartheid must be healed and the people have to reach out to one another across the boundaries of race. This was also the intention of the Truth and Reconciliation Commission (TRC). Desmond Tutu (1998:6) emphasised that it is the responsibility of every South African to persevere even after the activities of the Commission had ended. It is in this regard that believers can make a difference in society by serving each other through love.

A practical example of such service is found in the Letsema Healing Circle approach, which was designed by Ramphele (2012:182) to heal wounded people in South Africa and enable them to become engaged citizens. The Letsema Healing Circle approach starts with the understanding that before you can walk together as a people you need to sit down and talk. ${ }^{1}$

1.According to Ramphele (2012:182), "the African tradition dialogue platform is a circle and it constitutes a level playing field that includes everybody and places everyone on the same plane making eye contact possible. Circles also allow growth without on the same plane making eye contact possible. Circles also allow growth without
disrupting form - one simply makes the circle bigger to embrace newcomers or additional entrants.' 
Taking the cultural uses of the people into consideration is an important step in establishing $u b u n t u$ amongst the South African people.

The Letsema Healing Circle approach is represented in Box 1.

The purpose of this approach is to meet the community at the level where they are at that point in time and then to create the necessary space for them to talk about the wounds of the past and to process the pain in the light of the larger picture of the South African people. In this process everyone is empowered to assume responsibility for his or her own life and circumstances by utilising available resources, without waiting for the government or other institutions to change their destiny. Thus, the members of the community serve each other, they are healed and they can strive for the common goal of building a nation. The Letsema Healing Circle approach is currently used by the National Departement of Health in the Eastern Cape, Mpumalanga and the North-West Province. The aim is to integrate the different race groups in a nonthreatening manner (Ramphele 2012:196).

Although the Letsema Healing Circle approach has a clinical focus on the improvement of the medical aspects of the people in the African culture, to my mind it connects to the Reformational theology. The Reformational view of life is a wide, comprehensive vision, as it is not unilaterally theocentric (only directed at God), or cosmocentric (only directed at the creation), or nomocentric (only directed at the law of God), but it comprises all three ways of viewing life (Van der Walt 1999:21). The Refomational view of life explains how believers should serve God by obeying his laws - norms and values - in his creation and in that way serve society through love.

With reference to Osmer's model, the following normative aspects have emerged from the above-mentioned:

- Christians are responsible for showing love to fellow human beings as the only antidote to injustice in society. This does not mean tolerating others because everything is acceptable, good and right, but living in society according to biblical values and norms.

- Living according to biblical values and norms becomes a starting point in communication with a view to evangelisation.

- Discovering their identity in God will enable believers to live according to the will of God in society. Their identity

BOX 1: A processed view on the Letsema Healing Circle diagram of Ramphele (2012)

\begin{tabular}{|ll|}
\hline Preparation: Core-team for big llima & - Module 1: Enter in dialogue with the \\
& village people and painting the future \\
- Module 2: Use sandboxes and other & strategic planning models \\
- Module 3: Big llima multi-stakeholder & dialogues \\
Actual community llima & - Projects are implemented in two stages: \\
& - Module 4: short term projects \\
& - Module 5: medium and long-term \\
- projects & - End result: Community action
\end{tabular}

Source: Adapted from Ramphele, M., 2012, Conversations with my sons and daughters, Penguin Books, Johannesburg is not merely a cognitive conviction, but also a practical way of living through faith and love.

- Believers receive the command to continue the ministry of Jesus in the world and they will only be able to do that under the guidance of the Holy Spirit.

\section{Practical theology and service: Service provided by the Mamas Africa through love}

According to Osmer's model (2008), the focus in this section is on the empirical aspects of the service through love by the Mamas Africa. The section is presented in two sections. The first contains the descriptive task of priestly listening that takes place in a spirituality of presence (Osmer 2008:33). In this section, a qualitative investigation is undertaken into the activities of the women who serve their society with love every day. The second section concerns the interpretative task performed in a spirituality of sagely wisdom (Osmer 2008:81). In that section, the findings of the empirical research are evaluated. According to Neuman (1997:14) and Janse van Rensburg (2007a:7, 2007b:8), the aim of a qualitative study is to construct the cultural context in which the events take place. The participants in the research were selected because they were serving the community through Christian love. This measure ensured that those selected would be able to give valuable insights into the phenomenon under investigation. In observing the participants and in trying to understand their experiences, actions, emotions and the events of which they were part, I focussed on their emotions and sincerity. Interviews were conducted in a non-structured manner. Though the approach was subjective, the aim was not to get answers to questions or to test hypotheses, but to understand the experience of the participants and to observe their reactions.

\section{The service through love of the Mamas Africa}

The Mamas Africa are women who play leading roles in their communities because of their religious conviction and their vision to build a community, independent of any political, church or other institution. Five participants were selected for interviews. Three of them were from the group who had been previously disadvantaged by apartheid and the other two women were from the group who had benefited from apartheid. In this report, participants from the disadvantaged group are identified by the abbreviations WD1, WD2, WD3 (WD = Women disadvantaged because of apartheid), and those who benefited from apartheid are identified by the abbreviations WB1, WB2 (WB =Women who benefited from apartheid). Information obtained through the interviews is given below. The information is given with written consent of all the participants.

The first Mama Africa (WD1) was 79 years old at the time of the interview and she told me she was a founder member and manager of a day care centre for old people. She stated that she received no subsidies from the government and was dependent on sponsors and the goodwill of others. She 
recalled that her passion had been kindled when, taking on the care of her own mother and her mother's sister, she had become conscious of the need for old-age care in the community. She testified to an intimate relationship with God, her dependency on him and her prayers that were answered. Her vision was to restore the honour and the human dignity of the aged. From the interview, it became clear that the service to the aged included amongst others, daily transport to and from the centre, physical care of the aged by attending to their hygiene and medical needs, provision of meals from their own vegetable garden, et cetera. My overwhelming impression was that, despite her age, the Mama chose to be involved in society and to serve others through love.

The second Mama Africa (WD2) was a 65-year-old widow when I interviewed her. She said that she operated a vegetable garden project together with three other women at the Tlokwe Secondary School in Ikageng. To me as the interviewer it was remarkable that those Mamas, just like the first one, were dependent on sponsorships. Moreover, they did all the physical work themselves. From the garden they provided basic food to more or less 70 orphans daily. The Mama interviewed informed me that the children were not receiving the love of a mother, because their parents were dead (mostly because of HIV). As their gogo (grandmother), she said, she could give them love and hope for the future. She testified to her love for God and that it enabled her to provide service to society through the vegetable garden project. She confessed that as she had initially not known how to start the project, she had asked advice from another (white) woman who was involved in the informal settlement - also because of her faith. The motivation of the latter woman, according to my interviewee, was 'to exploit the gold that God placed in every human being' so that every one may live to the honour of God. I regard this story as an example of what may happen when one woman is prepared to serve - a process of providing service is set off and gains momentum when more and more people become involved in similar projects.

The third Mama Africa (WD 3) was a 36-year-old single mother of three children at the time of the interview. She informed me that she worked for a community project that was funded by endowments from businesspersons. As part of the project, instructors taught computer literacy and skills to people of the community in order to help them find work. The Mama added that she was also actively involved in social work and the teaching of life skills. She told me that she had always thought that she could only be a domestic worker, that is, a cleaner of other people's homes, but that she had become a 'mind cleaner'. She testified that her passion had come to life by reading spiritual books - her reading had awakened a hunger for God in her. Having come to know him she was serving him in total commitment, also in the church.

The fourth Mama Africa (WB 4) said she was 53 years old and that she had a heart and a passion for service to children. Initially, she had taken care of children removed from their parents by social workers. She had gradually acquired more and more qualifications to guide children to healing by means of play therapy. (I may add that she is currently in the process of completing her PhD in play therapy.) She told me that, eleven years ago, she had started serving society through a stimulation and feeding project in a less privileged neighbourhood. At the time of the interview, people of all races were served by the project. One of the objectives of the non-profit organisation was to put people at ease with people of other races and cultures and to establish involvement with one another. She shared information with me about another of her services, namely the presentation of children's evangelisation weeks in a community of people of mixed race. She explained that during those weeks, children with problems were identified and their problems addressed. She informed me that she had established a network of pastoral counsellors and social workers who were helping less privileged children of all races. She was also caring for a 15-year-old black boy whose parents had died. My impression of the Mama is that she had a deep faith and lived out her faith by providing service to children and by helping them to embrace a vision and hope for the future.

The fifth Mama Africa (WB 5), who was also 53 years old at the time of the interview, likewise told me that she provided service to children. She said she had been a full-time teacher, but had retired from the occupation to devote all her attention to helping traumatised children. (It may be mentioned that she has just completed her PhD studies in child therapy.) The Mama told me she had become aware of the injustices of apartheid whilst she and her family were living in a homeland during the years of apartheid. Since then, she has provided service to children of all races and cultures through play and art therapy. It also became clear from the interview that, apart from practising as a private pastoral counsellor, one of her priorities was visiting a children's home every two weeks for two days at a time. During those visits, she guided children to emotional healing. She confessed that in her youth she had thought she was better or more civilised than other people were. Only after realising that the emotions, inner conflict and spiritual consciousness of all people irrespective of their race or culture - were the same, had she come to love all people as human beings. It was clear to me that this conviction had led her to commence service to children of all races and cultures. The Mama attested to a deep faith and to pursuing her service with a dependence on the Holy Spirit.

\section{Evaluation of findings of the empirical research}

The number of challenges that the South African people experience at grass-roots level is legion. Firstly, change is a slow and painful process. Every one of these women had to make a personal commitment to serve society through love. It would have been easier for some of them to blame the system for their circumstances, but they chose to assume responsibility for themselves and for others. Secondly, change requires that personal boundaries must be shifted. Making the decision to become actively involved in society may be intimidating initially, but the mutual bonding that flows forth from involvement contributes to a feeling of solidarity that allows the women to persevere. 
All the women function independently of the government, church and other institutions. They provide their services in their personal capacity. All of them testify to the fact that they had to overcome inner conflicts and prejudices before they could serve others through faith and love. Jesus said during his ministry on earth, ' $[b]$ y this all men will know that you are my disciples, if you love one another' (Jn 13:35).

I came under the impression that visible love distinguishes these (ordinary) women from others. The women provide their services because Jesus' love compels them to serve others with his love (2 Cor 5:14). WD3 remarked that she could not change the destiny of everyone, but she could help people one by one, and in their turn, they could help others. Because a few women decided to live up to the biblical values and norms to serve others, a process was set off and gained momentum.

Though these women had no knowledge of the principles advocated by the Letsema Healing Circle approach, it was clear to me that they unknowingly applied the principles of this approach to their service to society. They began to serve society precisely by empowering themselves and by assuming responsibility for their own circumstances, utilising available resources.

\section{Practical theology and service: The praxis of providing service through love}

The last aspect of Osmer's model is the pragmatic task in a spirituality of servant leadership (Osmer 2008:183). The focus falls on the way in which the findings of the research may be applied to praxis in order to make a difference in the South African society by showing Christian love in serving others. If believers want to serve society through love because of their faith in God, it is necessary that they acknowledge the human dignity of their fellow human being. According to Vorster (2011:11), a Christian view of human dignity is that all life - irrespective of race or culture - should be taken seriously. Therefore, the interests of other people should be cared for by pleading for the interests of the community in preference to the right of the individual's privacy. True salvation, according to Vorster (2011:81), implies in the first place a restored relationship with God through the reconciling death of Jesus Christ on the cross.

Salvation, however, also has a horizontal dimension when believers find themselves in a new relationship with other people. Because of the example of the mediatorship of Jesus, believers must also be mediators who become actively involved in society. Moltmann (1978) writes the following about this:

Only those who have found themselves can give themselves. Only as I know the meaning of life can I act meaningfully for others. Only as I have become free can I free others without subjecting them to the new authoritarianism of my own ideals. Christian meditation and contemplation lead us to discover our own self as accepted, freed and redeemed by God in the comprehensive context of his history with the world. When we meditate upon Christ's history and through the Spirit experience our own history with Christ, we find not only ourselves, but also our place and our personal tasks within God's history with the world. (p. 45)

Marion (1992:472) says: 'Ama ut intelligas - love, so that you might understand.' I am of the opinion that the opposite of love is not hate, but fear. As long as people are controlled by fear, they will not reach out to other people to serve them in love and thus eventually understand them. Fear isolates people and causes everyone to live self-indulgently. Because of their relationship with God, believers can overcome this fear and serve their fellow human beings under the guidance of the Holy Spirit (Adeyemo 2006:1477). The result is that believers are changed and renewed inwardly to fulfil the purpose of their creation. Olthuis (2012) adds the following:

Reason, transformed by and in the service of love, will then have an eye for difference not in order to close it down or marginalise it, but in order to approach and connect with it, and let it be. Because God is Love and that Love is stronger than death, we live, not by Fortune or Blind Chance, but by Grace and Truth. Such a vision of and for Love encapsulates the heart of what could be called a Christian post-postmodern worldview. (p. 5)

Although this research focussed on the service of women in their personal capacity independent of their different congregations, Van der Walt (2007:79) points out that the church should characteristically be a missionary organisation with an outward focus. Believers have the calling to be witnesses (Ac 1:8; 13:4-7). This brings with it a big responsibility: 'It means inter alia to testify (1) to others (2) about something/someone (3) that you have seen and/or heard or only believe in which is (4) of ultimate importance' (Van der Walt 2007:80). Giving testimony must be holistic. Believers must give testimony in word and deed. Van der Walt (2007) explains the relationship between word and deed saying:

The relationship between these two facets of mission is so seamless that one should rather speak of words with deeds or deeds with words, than words and deeds or deeds and words. (p. 80)

Love should be shown specifically and concretely in all relationships in the lives of believers. To Van Wyk (2001:149) a church without living love is just as unimaginable as a church without a sound doctrine. Doctrine and life, confession and love, orthodoxy and orthopraxis are irrevocably part of being a living church.

If believers would want to become involved in society by providing a service, certain core moments, according to Van der Walt (1999:22), are necessary. The first is a new vision regarding their calling. Providing a service is not limited to the special church offices, but all believers receive the divine command to serve society through love in different areas. Secondly, it is of utmost importance to realise that love is not a feeling, but the will or law of God. Serving society through love is therefore obeying God's command of love. 
Regarding Osmer's model, the following pragmatic aspects may be deduced from the above-mentioned:

- If believers wish to serve society through love because of their faith in God, it is necessary that they acknowledge the human dignity of their fellow human beings.

- When believers live up to the demands of love in society, the result is reconciliation, as well as an understanding of and respect for one another's cultures. As long as people are controlled by fear, they will not reach out to other people to serve them in love and thus understand them eventually.

- The church should characteristically be a missionary organisation with an outward focus.

- Believers have the calling to be witnesses in word and deed.

- True love for the fellow human being decreases the number of evil phenomena such as apartheid, crime and corruption, and may even make those disappear.

\section{Conclusion}

Paul commands believers to serve one another through love. In this research, the different services provided to society by five Mamas Africa were investigated as examples of living up to the demands of this command. Although the fundamental principle of the Christian faith is that the human being is saved through grace because of the reconciling death of Jesus Christ on the cross and not because of merit, believers still have the command to live up to the demands of love for God and their neighbour. The spiritual life of believers is not merely a cognitive conviction, but is permeated by the love for God and hence influences and changes their entire human existence. The people of South Africa are still struggling to overcome the wounds of apartheid. Politicians wishing to promote the bonding and building of the nation continuously remind the people of the concept of Ubuntu. Despite uncertainties regarding the future there are believers who make a difference in their environment by serving society at grass roots level every day. The empirical research focussed on the services of five Mamas Africa that make life of other humans easier, because the Mamas serve others through the love of Jesus Christ. The times, in which we live call for a post-postmodern view, namely assuming Christian responsibility to be free and to serve one another through love. Eventually this means unconditional love and acceptance that brings renewal and change in society.

\section{Acknowledgements Competing interests}

The author declares that she has no financial or personal relationship(s) that may have inappropriately influenced her in writing this article.

\section{References}

Adeyemo, T. (ed.), 2006, 'Africa Bible Commentary. A one-volume commentary written by 70 African scholars', Word Alive Publishers, Nairobi.

Boraine, A., 2008, A life in transition, Struik, Cape Town.

Breed, G. \& Breed, D.G., 2010, 'Besinning oor die diakonale dienswerk na aanleiding van Handelinge 6:1-7', In die Skriflig/In Luce Verbi 44(3/4), 627-653. http:// van Handelinge $6: 1-7$ ', In die Skrif
dx.doi.org/10.4102/ids.v44i3/4.165

Getz, G.A., 1989, Serving one another. How do you measure up as a Christian servant? Victor Books, Wheaton, IL.

Janse van Rensburg, J., 2007a, 'Navorsingsmetodologie', voordrag gelewer by ' $n$ seminaar in navorsingsmetodologie, Noordwes-Universiteit, Potchefstroom, 09 Maart.

Janse van Rensburg, J., 2007b, 'Navorsingsmetodologie', voordrag gelewer by ' seminaar in navorsingsmetodologie, Noordwes-Universiteit, Potchefstroom, 30-31 Augustus.

Kossé, K., 2006, 'Unity of believers', in T. Adeyemo (ed.), Africa Bible Commentary, pp. 1288 , World Alive Publishers, Nairobi.

Lawler, M.G., 2004, 'Being Christian and the service of Love and Justice', Liturgical Ministry 13(Winter), 10-22.

LenkaBula, P., 2008, 'Beyond Anthropocentricity - Botho/Ubuntu and the quest for economic and ecological justice in Africa', Religion \& Theology 15(3/4), 375-394.

Marion, J.L., 1992, 'Christian philosophy and charity', Communio 19(Fall), 463-473.

Mnyaka, M. \& Motlhabi, M., 2005, 'The African concept of ubunthu/botho and its socop-moral significance', Black Theology: An International Journal 3(2), 215-237. http://dx.doi.org/10.1558/blth.3.2.215.65725

Moltmann, J., 1978, The open church. Invitation to a Messianic life-style, SCM Press, London.

Neuman, W.L., 1997, Social research methods, 3rd edn., Allyn and Bacon, Boston, MA.

Olthuis, J.H., 2012, 'A vision of and for love: Towards a Christian post-postmodern worldview', Koers - Bulletin for Christian Scholarship 77(1), 1-7. http://dx.doi. org/10.4102/koers.v77i1.28

Osmer, R., 2008, Practical theology: an introduction, Eerdmans, Grand Rapids, MI.

Ramphele, M., 2012, Conversations with my sons and daughters, Penguin Books, Johannesburg.

Tutu, D., 1998, 'The Truth and Reconciliation Commission', in C.W. du Toit (ed.), Confession and reconciliation, pp. 4-6, Research Unit for Theology and Religion, UNISA, Pretoria.

Van der Walt, B.J., 1999, Godsdiens en samelewing, Potchefstroomse Universiteit vir Christelike Höer Onderwys, Potchefstroom. (Wetenskaplike bydraes van die PU vir $\mathrm{CHO}$ ).

Van der Walt, B.J., 2007, Transforming power. Challenging Contemporary Secular Society, Institute for Contemporary Christianity in Africa, Potchefstroom.

Van Wyk, J.H., 2001, 'Kerk van geloof, hoop en liefde', in J.H. van Wyk (red.), Kerk en Christenwees vandag, bl. 145-158, Potchefstroom Teologiese Publikasies, Potchefstroom.

Vorster, J.M., 2011, 'An ethics of hope for moral renewal in South Africa', Journal of Theology for South Africa 140(July), 4-19.

Zorrilla, H., 1995, 'A service of sacrificial love', Direction 24(Spring), 74-85. 